\title{
Synthesis of $2 H$-furo[2,3-c]pyrazole ring systems through silver(I) ion-mediated ring-closure reaction
}

\author{
Vaida Milišiūnaitè ${ }^{1,2}$, Rūta Paulavičiūtè ${ }^{1}$, Eglè Arbačiauskienè ${ }^{1}$, Vytas Martynaitis ${ }^{1}$, \\ Wolfgang Holzer ${ }^{3}$ and Algirdas Šačkus ${ }^{* 1,2}$
}

\author{
Full Research Paper \\ Address: \\ ${ }^{1}$ Department of Organic Chemistry, Kaunas University of Technology, \\ Radvilènu pl. 19, Kaunas LT-50254, Lithuania, ${ }^{2}$ Institute of Synthetic \\ Chemistry, Kaunas University of Technology, K. Baršausko g. 59, \\ Kaunas LT-51423, Lithuania and ${ }^{3}$ Department of Pharmaceutical \\ Chemistry, University of Vienna, Althanstrasse 14, Vienna 1090, \\ Austria \\ Email: \\ Algirdas Šačkus* - algirdas.sackus@ktu.It \\ * Corresponding author \\ Keywords: \\ 5-endo-dig cyclization; $2 \mathrm{H}$-furo[2,3-c]pyrazole; pyrazole; silver(I) \\ catalyst; Sonogashira coupling
}

Beilstein J. Org. Chem. 2019, 15, 679-684.

doi:10.3762/bjoc. 15.62

Received: 08 January 2019

Accepted: 04 March 2019

Published: 14 March 2019

Associate Editor: B. Stoltz

(c) 2019 Milišiūnaitè et al.; licensee Beilstein-Institut. License and terms: see end of document.

\begin{abstract}
Fused pyrazole ring systems are common structural motifs of numerous pharmaceutically important compounds. Nevertheless, access to derivatives of the aromatic $2 H$-furo[2,3-c]pyrazole ring system is still quite limited, and their chemistry and functional properties remain largely underexplored. The current study investigates routes to construct this system from easily accessible starting materials using metal-catalyzed reactions. A simple and efficient procedure to access the $2 H$-furo[2,3-c]pyrazole ring system was developed by employing the silver(I) ion-mediated ring-closure reaction of 4-alkynyl-3-hydroxy-1-phenyl-1H-pyrazoles as a key step. The required intermediate hydroxyalkynyl substrates for this reaction were prepared by a Pd-catalyzed coupling of 4-iodo-1-phenyl-1H-pyrazol-3-ol with ethyne derivatives. The structures of the obtained target compounds were unequivocally confirmed by detailed ${ }^{1} \mathrm{H},{ }^{13} \mathrm{C}$ and ${ }^{15} \mathrm{~N}$ NMR spectroscopic experiments, HRMS and a single-crystal X-ray diffraction analyses. This silver(I)-mediated 5-endo-dig cyclization of readily available 4-alkynyl-3-hydroxy-1H-pyrazoles can be used as an efficient method to access many novel 2,5-disubstituted $2 H$-furo[2,3-c]pyrazoles.
\end{abstract}

\section{Introduction}

Heterocyclic ring systems possessing a pyrazole ring fused to an oxygen-containing six-membered heterocycle are present in a wide variety of biologically active compounds. For example, the 1,4- and 2,4-dihydropyrano[2,3-c]pyrazole ring systems [1] often represent the main structural motifs of anticancer [2-4], anti-inflammatory [5], and antidiabetic agents [6]. The numerous known methods for the preparation of these compounds are generally based on multicomponent reactions of an aromatic 
aldehyde, a $\beta$-keto ester, a hydrazine and malononitrile [7]. In a similar reaction using a pyridinium ylide instead of malononitrile, the dihydro- $1 H$-furo[2,3-c]pyrazole system, consisting of an aromatic pyrazole ring fused with a five-membered 2,3dihydrofuran ring, was formed [8]. Derivatives of the latter system are known for their antimicrobial [9] and antiproliferative activities [10]. Nevertheless, methods to access $2 H$-furo[2,3-c]pyrazoles, where both the fused pyrazole and furan moieties are aromatic, are still quite limited, and their chemistry and functional properties remain largely underexplored. Huang et al. have reported the synthesis and the evaluation of antiplatelet and anti-allergic activities of 2,3,4-trisubstituted $2 H$-furo[2,3-c]pyrazole-5-carboxylic acids and related carboxamides $[11,12]$. The aforementioned carboxylic acids have been prepared by bromination of the corresponding pyrano[2,3-c]pyrazol-6(1H)-one derivatives followed by heating of the obtained 5-bromo derivatives in the presence of sodium alkoxide [11]. Notably, the $2 H$-furo[2,3-c]pyrazole ring system is structurally similar to the benzo $[b]$ furan system, which is a privileged motif in natural products and biologically active compounds $[13,14]$. As a result, numerous strategies have been developed for the construction of benzo[b]furan and its derivatives [15-18]. For example, Damera et al. reported an efficient synthesis of 2-substituted benzo[b]furans with good yields by the base-promoted cyclization of easily accessible 2-alkynylphenols [19]. Recently, 2-arylbenzo[b]furans were conveniently synthesized by the one-pot tandem Hiyama alkynylation/cyclization reaction between 2-iodophenol and (triethoxysilyl)alkynes [20]. In recent years silver and gold salts have found application as versatile and mild catalysts to access the benzo[b]furan ring system through intramolecular cyclization of 2-alkynylphenol substrates [21], including preparation of 2-benzofuranmethanamines [22] and 4-indolylbenzo[b]furans [23] in the presence of $\mathrm{AgNO}_{3}$ and AgOTf, respectively, and 2-phenylbenzo[b]furans, where $\mathrm{AuCl}_{3}$ or a mixture thereof with AgOTf has been used to promote the appropriate cyclization [24].

In the present work, we describe a method for the construction of the $2 H$-furo[2,3-c]pyrazole ring system by a Sonogashiratype alkynylation of 4-iodopyrazol-3-ol and subsequent intramolecular 5-endo-dig cyclization of the obtained hydroxyalkynyl substrate mediated by a $\operatorname{Ag}(\mathrm{I})$ catalyst.

\section{Results and Discussion}

The synthetic strategy designed to construct the $2 H$-furo[2,3$c$ pyrazole ring system employs a hydroxyethynyl substrate that contains adjacent ethyne and hydroxy groups on the pyrazole core (Scheme 1). As a starting material, we used 1-phenyl-1Hpyrazol-3-ol (1), which is readily accessible from the oxidation of 1-phenyl-3-pyrazolidinone [25,26]. Recently, we used this scaffold to obtain the $2 H$-pyrazolo[4,3-c]pyridine [27,28], pyrazolo[4,3-f][1,2,3] triazolo[5,1-c][1,4]oxazepine [29] and pyrazolo[4',3':3,4]pyrido[1,2-a] benzimidazole [30] ring systems as well as to prepare building blocks for the construction of optoelectronic materials and fluorescent organic nanoparticles [3134].

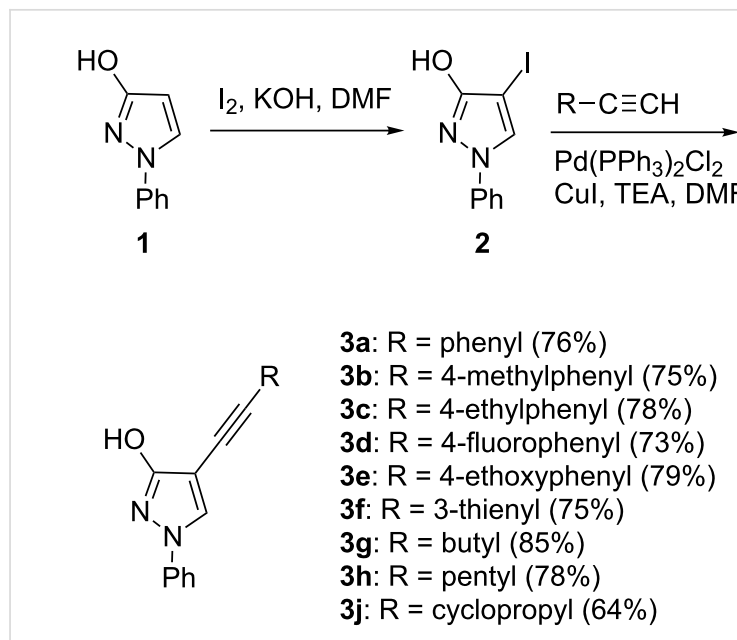

Scheme 1: Preparation of hydroxyalkynyl substrates from 1-phenyl1 -pyrazol-3-ol (1).

The iodination of $\mathbf{1}$ with iodine in the presence of $\mathrm{KOH}$ in DMF afforded 4-iodo-1 $H$-pyrazol-3-ol 2 [26]. We have previously shown that the Sonogashira-type coupling of the aforementioned iodinated compound with phenylacetylene under standard reaction conditions $\left(\mathrm{Pd}\left(\mathrm{PPh}_{3}\right)_{2} \mathrm{Cl}_{2}, \mathrm{CuI}\right.$, and TEA) gives 4-(phenylethynyl)-substituted pyrazolol 3a [26]. When various het(aryl)- and alkylacetylenes were used in the coupling with 2 under the same reaction conditions, compounds $\mathbf{3 b}-\mathbf{j}$ were obtained in $64-85 \%$ yield (Scheme 1).

Having prepared the series of hydroxyethynyl substrates $\mathbf{3 a}-\mathbf{j}$, the optimal conditions for the subsequent cyclization reaction were next investigated using 3a as the model compound (Table 1). First, we attempted the desired cyclization of 3a to $2 \mathrm{H}$-furo[2,3-c]pyrazole 4a using the synthetic protocol involving $\mathrm{Cs}_{2} \mathrm{CO}_{3}$ in dry DMF at $60{ }^{\circ} \mathrm{C}$, which has been previously successfully employed for the preparation of benzo $[b]$ furans by the cyclization of $o$-alkynylphenols [19]. Unfortunately, no addition of the hydroxy group across the carbon-carbon triple bond was observed even after heating the reaction mixture under analogous reaction conditions for 24 hours (Table 1, entry 1).

The formation through a 5-endo-dig cyclization of some amount of compound 4a was detected by LC-MS measurements only when the reaction mixture contained $\mathrm{Cs}_{2} \mathrm{CO}_{3}$ as a base and was 
Table 1: Cyclization of compound 3a.

\begin{tabular}{|c|c|c|c|c|c|}
\hline & & $\begin{array}{l}\text { bas } \\
\text { DM }\end{array}$ & & & \\
\hline Entry & Base & Catalyst & Temp $\left({ }^{\circ} \mathrm{C}\right)$ & $t(\mathrm{~h})$ & Yield 4a \\
\hline 1 & $\mathrm{Cs}_{2} \mathrm{CO}_{3}$ & - & 60 & 24 & no product \\
\hline 2 & $\mathrm{Cs}_{2} \mathrm{CO}_{3}$ & - & 120 & 96 & traces \\
\hline 3 & $\mathrm{~K}_{2} \mathrm{CO}_{3}$ & - & 120 & 96 & $47 \%$ \\
\hline 4 & $\mathrm{~K}_{2} \mathrm{CO}_{3}$ & {$\left[\left(\mathrm{Ph}_{3} \mathrm{P}\right) \mathrm{Au}\right] \mathrm{Cl}(10 \mathrm{~mol} \%)$} & 120 & 14 & $69 \%$ \\
\hline 5 & $\mathrm{~K}_{2} \mathrm{CO}_{3}$ & AgOTf (10 mol \%) & 120 & 14 & $92 \%$ \\
\hline 6 & $\mathrm{~K}_{2} \mathrm{CO}_{3}$ & AgOTf (10 mol \%) & 80 & 96 & $15 \%$ \\
\hline 7 & - & AgOTf (1 equiv) & 120 & 96 & traces \\
\hline 8 & $\mathrm{Cs}_{2} \mathrm{CO}_{3}$ & AgOTf (10 mol \%) & 120 & 96 & $69 \%$ \\
\hline
\end{tabular}

heated at $120{ }^{\circ} \mathrm{C}$ for 4 days (Table 1 , entry 2). Surprisingly, when $\mathrm{K}_{2} \mathrm{CO}_{3}$ was used instead of $\mathrm{Cs}_{2} \mathrm{CO}_{3}$, the desired 2-phenyl-2 $\mathrm{H}$-furo[2,3-c]pyrazole was obtained in a significantly higher yield (47\%, Table 1 , entry 3$)$.

Some of the most effective catalysts for the electrophilic activation of alkynes under homogeneous conditions are gold(I) [35] and silver(I) [36] salts or complexes, and a broad range of versatile synthetic methods has been developed for the construction of carbon-heteroatom bonds using these types of catalysts. For example, the gold(I) catalyst $\left[\left(\mathrm{Ph}_{3} \mathrm{PAu}\right)_{3} \mathrm{O}\right] \mathrm{BF}_{4}$ was applied in the regioselective intramolecular cyclization of alkynols to construct bicyclic ethers [37], while the silver(I) catalyst AgOTf efficiently catalyzed the intramolecular cyclization of phenoxyethynyl diols into 2,3-unsaturated lactones [38]. In our case, the addition of $10 \mathrm{~mol} \%$ chloro(triphenylphosphine)gold(I) improved the yield of product 4 a to $69 \%$ (Table 1, entry 4). However the best results were obtained when AgOTf was used as a catalyst. In this case, the target product 4 a was obtained in an excellent $92 \%$ yield (Table 1, entry 5 ).

It is important to note that the reaction temperature had a significant effect on the yield of the product. When the temperature was lowered to $80^{\circ} \mathrm{C}$, the yield of the product did not exceeded $15 \%$ (Table 1 , entry 6 ). The presence of a base also plays a crucial role in the cyclization described herein, and the transformation of 3a to $4 \mathbf{a}$ did not occur in the presence of only the catalyst and without base (Table 1, entry 7). Finally, the reaction optimization experiments showed that the $\mathrm{Cs}_{2} \mathrm{CO}_{3} / \mathrm{AgOTf}$ system does not offer any advantages for this cyclization compared to the $\mathrm{K}_{2} \mathrm{CO}_{3} / \mathrm{AgOTf}$ system (Table 1, entry 8).
With the optimized conditions for the 5-endo-dig cyclization reaction identified, the scope of this transformation for the preparation of several 2,5-disubstituted $2 \mathrm{H}$-furo[2,3-c]pyrazoles was explored (Scheme 2). For substrates $\mathbf{3 b}-\mathbf{j}$, the reactions were complete after 14 hours at $120{ }^{\circ} \mathrm{C}$, and products $4 \mathbf{b}-\mathbf{j}$ were generated in fair to excellent yields.

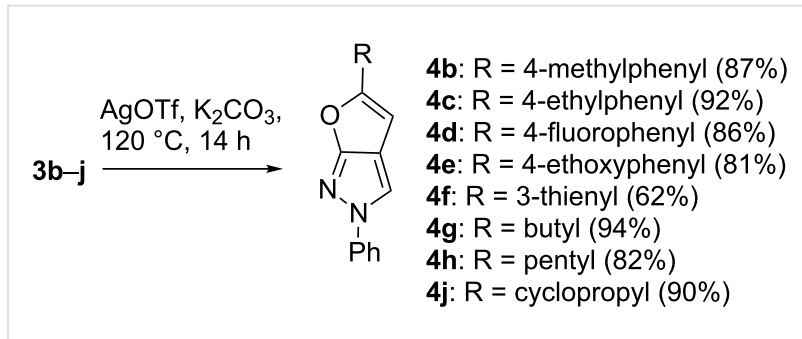

Scheme 2: Cyclization of hydroxyalkynyl substrates to 2,5-disubstituted $2 \mathrm{H}$-furo[2,3-c]pyrazoles.

The structural assignments of $\mathbf{4 a}-\mathbf{j}$ were based on multinuclear NMR and IR spectroscopy as well as high-resolution mass spectrometry (HRMS) data and a single-crystal X-ray diffraction analysis. The ${ }^{1} \mathrm{H}$ NMR spectra of compounds $\mathbf{4 a}-\mathbf{j}$ revealed the characteristic $\mathrm{H}-3$ proton singlet in the $\delta 7.60-7.77 \mathrm{ppm}$ region as well as a $\mathrm{H}-4$ proton singlet in the $\delta 6.06-6.74 \mathrm{ppm}$ region. The ${ }^{13} \mathrm{C}$ NMR spectra of $\mathbf{4 a}-\mathbf{j}$ exhibited signals for the five carbon atoms of the $2 H$-furo[2,3-c]pyrazole ring system in the regions of $\delta 115.0-116.3$ for $\mathrm{C}-3, \delta$ 113.1-113.9 for C-3a, $\delta$ 94.5-96.8 for C-4, $\delta$ 156.1-163.8 for C-5 and $\delta$ 168.4-169.0 ppm for C-6a. The ${ }^{15} \mathrm{~N}$ spectra of $4 \mathbf{b}-\mathbf{e}$ exhibited signals for two nitrogen atoms in the regions of $\delta-169.4$ to -172.6 for $\mathrm{N}-2$ and $\delta-127.5$ to $-128.0 \mathrm{ppm}$ for $\mathrm{N}-1$. 
The structure of $\mathbf{4 d}$ was investigated additionally by single crystal X-ray analysis (Figure 1) [39].

The asymmetric unit of the crystal consists of two molecules $\operatorname{4d}(\mathbf{A})$ and $\mathbf{4 d}(\mathbf{B})$ held together by the weak $\mathrm{CH} \cdots \mathrm{N}$ type hydrogen bonds $\mathrm{C} 19-\mathrm{H} \cdots \mathrm{N} 51(\mathrm{C} \cdots \mathrm{N}=3.470(11) \AA, \mathrm{H} \cdots \mathrm{N}=2.60 \AA$, $\left.\mathrm{C}-\mathrm{H} \cdots \mathrm{N}=151^{\circ}\right)$ and $\mathrm{C} 69-\mathrm{H} \cdots \mathrm{N} 1(\mathrm{C} \cdots \mathrm{N}=3.355(11) \AA, \mathrm{H} \cdots \mathrm{N}=$ $2.51 \AA, \mathrm{C}-\mathrm{H} \cdots \mathrm{N}=144^{\circ}$ ), respectively, whose length and angles are typical for crystals of aza-heterocycles [40]. Although at first glance the molecules $4 \mathbf{d}(\mathbf{A})$ and $4 \mathbf{d}(B)$ appear to be identical, they differ in bond lengths and dihedral angles $\Phi$ from each other. The corresponding bond lengths of $2 H$-furo[2,3-c]pyrazole systems in $\mathbf{4 d}(\mathbf{A})$ and $\mathbf{4 d}(\mathbf{B})$ are given in Table 2 .

The lengths of the C-F bonds for molecules $4 \mathbf{d}(A)$ and $4 \mathbf{d}(B)$ are 1.356(10) $\AA$ and 1.392(11) $\AA$, respectively. All ring atoms of the $2 H$-furo[2,3-c]pyrazole moiety lie in almost one plane, but the phenyl substituents are slightly turned in relation to this plane (Table 3). a)

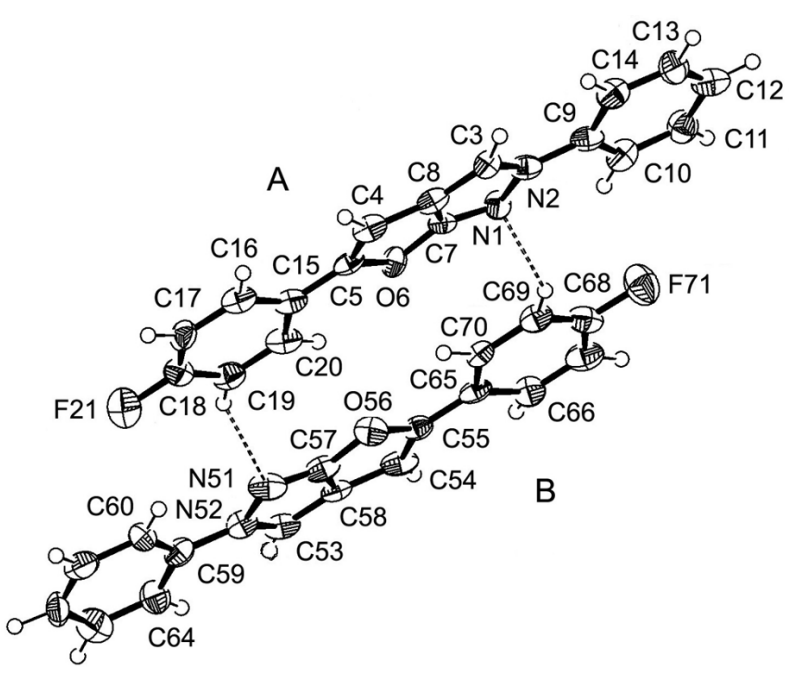

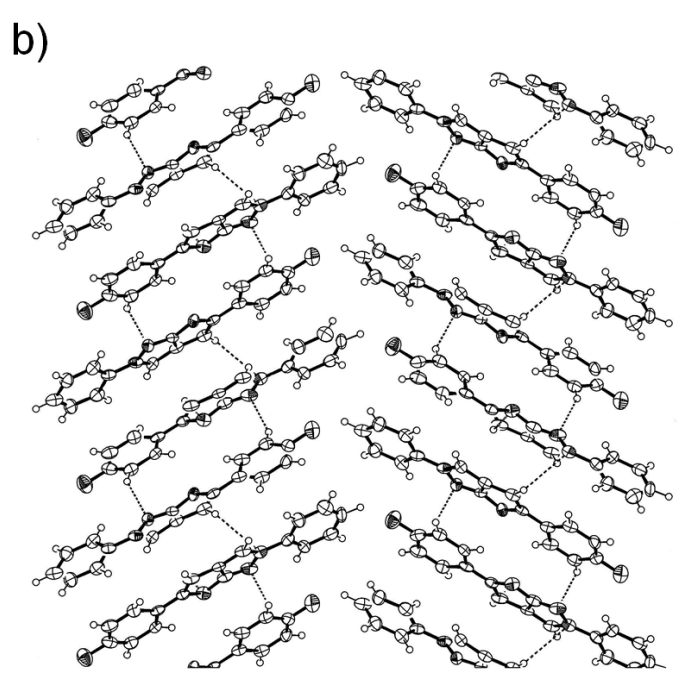

Figure 1: a) ORTEP diagram of the asymmetric unit consisting of two independent molecules $4 \mathbf{d}(\mathbf{A})$ and $\mathbf{4 d}(\mathbf{B})$; b) view (normal to (100)) of molecular packing in the crystal.

\begin{tabular}{|c|c|c|c|}
\hline Molecule 4d(A) & $d, \AA$ & Molecule 4d(B) & $d, \AA$ \\
\hline N1-N2 & $1.391(7)$ & N51-N52 & $1.407(8)$ \\
\hline N2-C3 & $1.378(8)$ & N52-C53 & $1.358(9)$ \\
\hline C3-C8 & $1.378(10)$ & C53-C58 & $1.371(11)$ \\
\hline C8-C4 & $1.457(11)$ & C58-C54 & $1.450(11)$ \\
\hline C4-C5 & $1.362(8)$ & C54-C55 & $1.337(9)$ \\
\hline C5-O6 & $1.401(8)$ & C55-O56 & $1.424(8)$ \\
\hline $\mathrm{O}-\mathrm{C} 7$ & $1.354(9)$ & O56-C57 & $1.365(10)$ \\
\hline C7-N1 & $1.317(11)$ & C57-N51 & $1.298(12)$ \\
\hline C7-C8 & $1.396(8)$ & C57-C58 & $1.405(9)$ \\
\hline
\end{tabular}

\begin{tabular}{|c|c|c|c|c|}
\hline Substitutent & Molecule 4d(A) & $\Phi$, deg & Molecule 4d(B) & $\Phi$, deg \\
\hline \multirow[t]{2}{*}{ phenyl } & C10-C9-N2-N1 & 7.64 & C60-C59-N52-N51 & 6.97 \\
\hline & C14-C9-N2-C3 & 10.09 & C64-C59-N52-C53 & 10.68 \\
\hline \multirow[t]{2}{*}{ 4-fluorophenyl } & C16-C15-C5-C4 & 9.71 & C66-C65-C55-C54 & 5.06 \\
\hline & C20-C15-C5-O6 & 6.51 & C70-C65-C55-O56 & 8.89 \\
\hline
\end{tabular}


The molecules in the crystal are located in columns made up of asymmetric units held by hydrogen bonds (Figure 1b).

\section{Conclusion}

In conclusion, we have demonstrated a new, three-step synthetic route to $2 H$-furo[2,3-c]pyrazoles starting from commercially available 1-phenylpyrazol-3-ol. Iodination of the latter compound with iodine in DMF smoothly afforded 1-phenyl-4iodopyrazol-3-ol, which can undergo a Pd-catalyzed coupling with terminal alkynes to give the corresponding 4-alkynyl-3hydroxy-1-phenyl-1 $H$-pyrazoles. The desired 5-endo-dig cyclization leading to the formation of the $2 H$-furo[2,3-c]pyrazole ring system is easily achieved by heating the aforementioned hydroxyalkynyl substrates with a base in DMF in the presence of a silver(I) catalyst.

\section{Supporting Information}

\section{Supporting Information File 1}

Experimental details and characterization data.

[https://www.beilstein-journals.org/bjoc/content/ supplementary/1860-5397-15-62-S1.pdf]

\section{ORCID ${ }^{\circledR}$ iDs}

Vaida Milišiūnaitè - https://orcid.org/0000-0002-5338-4621 Eglè Arbačiauskienè - https://orcid.org/0000-0003-1365-9990 Vytas Martynaitis - https://orcid.org/0000-0003-1147-6584 Algirdas Šačkus - https://orcid.org/0000-0002-1514-4934

\section{References}

1. Das, D.; Banerjee, R.; Mitra, A. J. Chem. Pharm. Res. 2014, 6, 108-116.

2. Salama, S. K.; Mohamed, M. F.; Darweesh, A. F.; Elwahy, A. H. M.; Abdelhamid, I. A. Bioorg. Chem. 2017, 71, 19-29. doi:10.1016/j.bioorg.2017.01.009

3. Yan, C.; Theodorescu, D.; Miller, B.; Kumar, A.; Kumar, V.; Ross, D.; Wempe, M. F. Bioorg. Med. Chem. Lett. 2016, 26, 5815-5818. doi:10.1016/j.bmcl.2016.10.021

4. Kashtoh, H.; Muhammad, M. T.; Khan, J. J. A.; Rasheed, S.; Khan, A.; Perveen, S.; Javaid, K.; Atia-tul-Wahab; Khan, K. M.; Choudhary, M. I. Bioorg. Chem. 2016, 65, 61-72. doi:10.1016/j.bioorg.2016.01.008

5. Zaki, M. E. A.; Soliman, H. A.; Hiekal, O. A.; Rashad, A. E. Z. Naturforsch., C: J. Biosci. 2006, 61, 1-5. doi:10.1515/znc-2006-1-201

6. Qvortrup, K.; Jensen, J. F.; Sørensen, M. S.; Kouskoumvekaki, I.; Petersen, R. K.; Taboureau, O.; Kristiansen, K.; Nielsen, T. E. PLoS One 2017, 12, e0162642. doi:10.1371/journal.pone.0162642

7. Myrboh, B.; Mecadon, H.; Rohman, M. R.; Rajbangshi, M.; Kharkongor, I.; Laloo, B. M.; Kharbangar, I.; Kshiar, B. Org. Prep. Proced. Int. 2013, 45, 253-303. doi:10.1080/00304948.2013.798566
8. Tangeti, V. S.; Siva Prasad, G. V.; Panda, J.; Varma, K. R. Synth. Commun. 2016, 46, 878-884. doi:10.1080/00397911.2016.1174781

9. Bondock, S.; Khalifa, W.; Fadda, A. A. Eur. J. Med. Chem. 2011, 46, 2555-2561. doi:10.1016/j.ejmech.2011.03.045

10. Tangeti, V. S.; Vasundhara, D.; Satyanarayana, K. V. V. V.; Pavan Kumar, K. S. Asian J. Chem. 2017, 29, 1525-1532. doi:10.14233/ajchem.2017.20550

11. Kuo, S.-C.; Huang, L.-J.; Teng, C.-M. 2,3,4,5-Substituted furo[2,3-c]pyrazole derivatives. U.S. Pat. Appl. US5240947A, Aug 31, 1993.

12. Huang, L.-J.; Kuo, S.-C.; Wang, J.-P.; Ishii, K.; Nakamura, H. Chem. Pharm. Bull. 1994, 42, 2036-2041. doi:10.1248/cpb.42.2036

13. Lütjens, H.; Scammells, P. J. Tetrahedron Lett. 1998, 39, 6581-6584. doi:10.1016/s0040-4039(98)01371-9

14. Heravi, M. M.; Zadsirjan, V.; Hamidi, H.; Tabar Amiri, P. H. RSC Adv. 2017, 7, 24470-24521. doi:10.1039/c7ra03551a

15. Yudin, A. K., Ed. Catalyzed Carbon-Heteroatom Bond Formation; Wiley-VCH Verlag GmbH: Weinheim, Germany, 2011. doi:10.1002/9783527633388

16. Heravi, M. M.; Zadsirjan, V. Curr. Org. Synth. 2016, 13, 780-833. doi:10.2174/1570179413666151218202156

17. Godoi, B.; Schumacher, R. F.; Zeni, G. Chem. Rev. 2011, 111, 2937-2980. doi:10.1021/cr100214d

18. Wu, X.-F.; Neumann, H.; Beller, M. Chem. Rev. 2013, 113, 1-35. doi:10.1021/cr300100s

19. Damera, K.; Ke, B.; Wang, K.; Dai, C.; Wang, L.; Wang, B. RSC Adv. 2012, 2, 9403-9405. doi:10.1039/c2ra21302h

20. Ao, J.; Liu, Y.; Jia, S.; Xue, L.; Li, D.; Tan, Y.; Qin, W.; Yan, H. Tetrahedron 2018, 74, 433-440. doi:10.1016/j.tet.2017.11.049

21. Blanc, A.; Bénéteau, V.; Weibel, J.-M.; Pale, P. Org. Biomol. Chem. 2016, 14, 9184-9205. doi:10.1039/c6ob01468b

22. Wongsa, N.; Sommart, U.; Ritthiwigrom, T.; Yazici, A.; Kanokmedhakul, S.; Kanokmedhakul, K.; Willis, A. C.; Pyne, S. G. J. Org. Chem. 2013, 78, 1138-1148. doi:10.1021/jo302554v

23. Ye, Y.; Fan, R. Chem. Commun. 2011, 47, 5626-5628. doi:10.1039/c1cc10137d

24. Zhang, Y.; Xin, Z.-J.; Xue, J.-J.; Li, Y. Chin. J. Chem. 2008, 26, 1461-1464. doi:10.1002/cjoc.200890265

25. König, H.; Götz, N.; Klein, U.; Eller, K. Process for producing N-substituted 3-hydroxypyrazoles. WO Patent WO1997003969, Feb 6, 1997.

Chem. Abstr. 1997, 126, 199566.

26. Arbačiauskienè, E.; Vilkauskaitè, G.; Eller, G. A.; Holzer, W.; Šačkus, A. Tetrahedron 2009, 65, 7817-7824. doi:10.1016/j.tet.2009.07.017

27. Milišiūnaitè, V.; Arbačiauskienè, E.; Řezníčková, E.; Jorda, R.; Malínková, V.; Žukauskaitè, A.; Holzer, W.; Šačkus, A.; Kryštof, V. Eur. J. Med. Chem. 2018, 150, 908-919. doi:10.1016/j.ejmech.2018.03.037

28. Arbačiauskienè, E.; Martynaitis, V.; Krikštolaitytè, S.; Holzer, W.; Šačkus, A. ARKIVOC 2011, No. xi, 1-21. doi:10.3998/ark.5550190.0012.b01

29. Arbačiauskienè, E.; Laukaitytè, V.; Holzer, W.; Šačkus, A. Eur. J. Org. Chem. 2015, 5663-5670. doi:10.1002/ejoc.201500541

30. Milišiūnaitè, V.; Arbačiauskienè, E.; Bieliauskas, A.; Vilkauskaitè, G.; Šačkus, A.; Holzer, W. Tetrahedron 2015, 71, 3385-3395. doi:10.1016/j.tet.2015.03.092 
31. Arbačiauskienè, E.; Kazlauskas, K.; Miasojedovas, A.; Juršènas, S.; Jankauskas, V.; Holzer, W.; Getautis, V.; Šačkus, A. Synth. Met. 2010, 160, 490-498. doi:10.1016/j.synthmet.2009.11.038

32. Arbačiauskienè, E.; Kazlauskas, K.; Miasojedovas, A.; Juršènas, S.; Jankauskas, V.; Holzer, W.; Getautis, V.; Šačkus, A. Dyes Pigm. 2010, 85, 79-85. doi:10.1016/j.dyepig.2009.10.007

33. Kazlauskas, K.; Kreiza, G.; Arbačiauskienè, E.; Bieliauskas, A.; Getautis, V.; Šačkus, A.; Juršènas, S. J. Phys. Chem. C 2014, 118 25261-25271. doi:10.1021/jp507707f

34. Kazlauskas, K.; Miasojedovas, A.; Dobrovolskas, D.; Arbačiauskienè, E.; Getautis, V.; Šačkus, A.; Juršènas, S. J. Nanopart. Res. 2012, 14, No. 877. doi:10.1007/s11051-012-0877-6

35. Dorel, R.; Echavarren, A. M. Chem. Rev. 2015, 115, 9028-9072. doi:10.1021/cr500691k

36. Fang, G.; Bi, X. Chem. Soc. Rev. 2015, 44, 8124-8173. doi:10.1039/c5cs00027k

37. Kubota, M.; Saito, T.; Miyamoto, K.; Hirano, K.; Wang, C.; Uchiyama, M. Chem. Pharm. Bull. 2016, 64, 845-855. doi:10.1248/cpb.c16-00204

38. Egi, M.; Ota, Y.; Nishimura, Y.; Shimizu, K.; Azechi, K.; Akai, S. Org. Lett. 2013, 15, 4150-4153. doi:10.1021/ol401824v

39. The CCDC deposition number of 5-(4-fluorophenyl)-2-phenyl-2H-furo[2,3-c]pyrazole (4d) is 1862867; formula $\mathrm{C}_{17} \mathrm{H}_{11} \mathrm{FN}_{2} \mathrm{O}$; unit cell parameters: $a, 5.4969(3) b, 16.2128(7)$ c, 28.8194(16), space group $P b n 2_{1}$.

40. Shivakumar, K.; Vidyasagar, A.; Naidu, A.; Gonnade, R. G.; Sureshan, K. M. CrystEngComm 2012, 14, 519-524. doi:10.1039/c1ce05997a

\section{License and Terms}

This is an Open Access article under the terms of the Creative Commons Attribution License (http://creativecommons.org/licenses/by/4.0). Please note that the reuse, redistribution and reproduction in particular requires that the authors and source are credited.

The license is subject to the Beilstein Journal of Organic Chemistry terms and conditions:

(https://www.beilstein-journals.org/bjoc)

The definitive version of this article is the electronic one which can be found at: doi:10.3762/bjoc. 15.62 